\title{
Maximizing learners' metacognitive awareness in listening through metacognitive instruction: An empirical study
}

Fahim, Mansoor

English Department, Science and Research Branch, Islamic Azad University, Tehran, Iran (dr.manfahim@yahoo.com)

Fakhri Alamdari, Ebrahim

English Department, Science and Research Branch, Islamic Azad University, Tehran, Iran (fakhri.iau.ac@gmail.com)

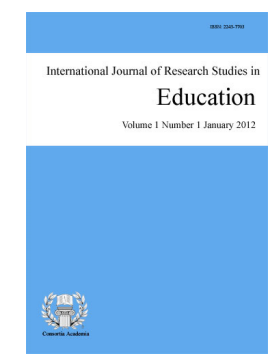

ISSN: $2243-7703$ Online ISSN: 2243-7711

OPEN ACCESS

\section{Abstract}

This paper reports on a small-scale study investigating the impact of metacognitive instruction on EFL learners' metacognitive awareness and their listening performance. The participants were 30 intermediate EFL listeners, who went through a ten-week intervention program in metacognition with its focus on prediction/planning, monitoring, evaluating, and problem solving The MALQ and a listening test were also used to track changes in metacognitive awareness and listening performance before and after the intervention. A comparison of pretest and posttest scores revealed that metacognitive instruction raised the learners' metacognitive awareness and helped them improve their listening comprehension ability.

Keywords: listening comprehension; metacognitive instruction; metacognitive awareness; metacognitive pedagogical sequence 


\section{Maximizing learners' metacognitive awareness in listening through metacognitive instruction: An empirical study}

\section{Introduction}

Listening comprehension, as a crucial language skill to develop, is at the heart of L2 learning, as the development of L2 listening can play a vital role in the development of other language skills (Dunkel, 1991; Rost, 2002; Vandergrift, 2007). Despite its importance, listening comprehension is often regarded as a big challenge and a great source of frustration for second and foreign language learners (Graham, 2006), which can lead not only to poor learners' performance but also to inadequate attention to listening instruction in the classroom (Lynch, 2011). The complexity of listening could be due to such external factors as speaker, text and content (Lynch, 2011), or it could be attributed to such reasons as the ephemeral nature of the listening input, the implicit nature of listening, and the difficulty in accessing the listening processes (Vandergrift, 2007). Besides, little attention has been given to the systematic practice in L2 listening (DeKeyser, 2007), with its focus on listening process than listening product (Vandergrift, 2004), as second or foreign language learners are rarely taught how to listen effectively although they are aware of the importance of this skill (Mendelsohn, 2001; Berne, 2004; Vandergrift, 2007).

One way to deal with the complexity of listening comprehension is to use "metacognitive instruction" as a process-based approach to facilitate the process of listening for language learners (Goh, 2008, 2010). A quick look at the recent body of research on second or foreign listening instruction advocates the urgent need for effective metacognitive strategy instruction to improve second language listening comprehension pedagogy. In the same vein, considering the manner through which metacognitive strategies are orchestrated in textbooks dealing with listening in Iranian EFL context, it can be realized that metacognitive strategies are still being taught in Iran through pre-listening, listening, and post-listening activities. Despite all the efforts teachers make to provide listeners with adequate support during listening activities in the classroom, the focus is still on listening product rather than listening process.

Although there is a string of research shedding light on the effect of metacognitive instruction on the listening performance and metacognitive awareness of learners in both ESL and EFL settings, the results are mostly inconclusive should we consider their various methodological orientations, the nature and the model of the intervention programs they were informed by, the sample size, and above all the contexts in which these studies were carried out, which can all constrain the generalizability of the results. Thus, lack of methodological consistency from the previous research on the one hand, and all the ongoing debates about metacognitive strategy instruction on the other, make it particularly challenging for teachers to figure out how to deal with metacognitive instruction in the classroom. Therefore, the focus of this study is to explore the effect of metacognitive instruction on the listening performance and metacognitive awareness of EFL learners in Iran.

\section{Theoretical background}

\subsection{The concept of metacognition}

The term 'metacognition', emanated from the field of psychology, is often simplified as thinking about thinking or cognition about cognition (Anderson, 2002), and it is defined as "knowledge concerning one's own cognitive processes and products or anything related to them" (Flavell, 1976, p. 232). Flavell (1979) deconstructed the term 'metacognition' into two broad components: (1) metacognitive experience, and (2) metacognitive knowledge. Metacognitive experience, as Hacker (1998) put it, concerns the “...ability to consciously and deliberately monitor and regulate ones' knowledge...” (p. 11) whereas metacognitive knowledge, 
Maximizing learners' metacognitive awareness in listening through metacognitive instruction

according to Livingston (1997), refers to knowledge and beliefs about factors that interact during a cognitive activity.

Flavell (1976) further divided metacognitive knowledge into three categories: person, task, and strategy knowledge. Person knowledge is the knowledge one has about oneself and others as cognitive processors, which can affect the success or failure in one's learning. Task knowledge is the knowledge one has about the information and resources one needs to undertake a task, which enables an individual to take into account factors that might contribute to the difficulty of a task, and strategy knowledge is the knowledge regarding the strategies which are likely to be effective in achieving goals and undertaking tasks. These three types of knowledge, as Wenden (1998) maintains, interact during the learning process and can, consequently, yield learning outcomes.

\subsection{Metacognitive instruction in listening}

Metacognitive instruction, as described by Vandergrift and Goh (2012), refers to "pedagogical procedures that enable learners to increase awareness of listening process by developing richer metacognitive knowledge about themselves as listeners, the nature and demands of listening, and strategies for listening" (p. 97). There has been a growing tendency for almost two decades for the use of metacognitive instruction to facilitate the process and outcome of listening. The pedagogical evidence supports the notion that metacognitive instruction can not only assist learners in what they choose to process learning, but also improve successful language learning through acquiring metacognitive strategies. In the same vein, Goh (2008) maintains that metacognitive instruction can inherently strengthen learners' awareness and their listening process, which can assist learners in using appropriate strategies. Commenting on the demand for such metacognitive instruction, Pressley (2002) asserts that learners need a long-term direct explanation, modeling strategies, and strategies with guided practice in order to use appropriate strategies in different contexts. Metacognitive instruction in listening can be presented to language learners in different forms. One such form, according to Mendelsohn (1998), is to go through a series of activities that encourage the use of planning, monitoring, and evaluating strategies for a given listening text.

Vandergrift and Goh (2012) proposed a new model of metacognitive instruction, known as "Metacognitive Pedagogical Sequence". This model, which provides learners with ample opportunities to exploit dialogic interactions in negotiating metacognitive strategies, is informed by sociocultural perspectives of learning, which merges two aspects of learning: "learning as an individual cognitive enterprise and learning as a social enterprise" (Vandergrift \& Goh, 2012, p. 93). Within this process-based approach, dialogic interactions, along with activities learners participate in, contribute to the overall learning and success of each individual in the interaction. The model can further provide learners with opportunities to enrich individual learning through peer dialogs and cooperation. The Metacognitive Pedagogical Sequence involves the instruction of metacognitive strategies in five sequential phases every session, which are presented in Figure 1.

\begin{tabular}{cc}
\hline \multicolumn{1}{c}{ Stages of listening instruction } & Related metacognitive strategies \\
\hline Planning/predicting stage &
\end{tabular}

Once listeners know topic and the text type, they predict types of information and possible words they may hear.

\section{First verification stage}

Listeners verify initial hypotheses, correct as required, and note additional information understood.

Listeners compare what they have written with their peers, modify as required, establish what needs resolution and decide on details that still need special attention.
Planning and directed attention

Monitoring

Monitoring, planning, selective attention 
Fahim, M. \& Fakhri Alamdari, E.

\section{Second verification stage}

Listeners verify points of disagreement, make corrections, and write down additional details understood.

Class discussion in which all contribute to reconstruction of the text's main points and most pertinent details, interspersed with reflections on how listeners arrived at the meaning of certain words or parts of the text.

\section{Final verification stage}

Listeners listen for information that they could not decipher earlier in the class discussion.

Monitoring and problem solving

Monitoring and evaluation

\section{Reflective stage}

Based on discussion of strategies used to compensate for what was not understood, listeners write goals for next

- Evaluation listening activities.

Figure 1. Listening instruction stages and related metacognitive strategies. Reprinted from Teaching and learning second language listening: Metacognition in action (p. 110), by L. Vandergrift and C. Goh, 2012, New York, NY: Rutledge.

The importance of metacognitive instruction and its impact on metacognitive awareness in listening has recently gained recognition in Second / Foreign language learning contexts. While there are a great number of empirical studies hosting evidence that learners' listening performance can be enhanced through the process-based instruction of metacognitive strategies (see Baleghizadeh \& Rahimi, 2011; Bozorgian, 2012, 2014; Coskun, 2010; Fahim \& Fakhri, 2014; Goh \& Hu, 2013; Goh \& Taib, 2006; Goh \& Yusnita, 2006; Mareschal, 2007; Rahimi \& Katal, 2013; Vandergrift \& Tafaghodtari, 2010), there are some others with mixed results in both EFL and ESL contexts, which found no immediate enhancement in the listening performance (see Chen \& Haung, 2011; Rahimi \& Katal, 2013) and metacognitive awareness (see Bozorgian, 2012, 2014) of learners as a result of metacognitive instruction. Some of these studies are discussed in depth below.

\subsection{Research into metacognitive instruction in listening}

Goh and Taib (2006) conducted a study, with its focus on listening process, through which they strove to investigate the effect of metacognitive instruction on young ESL learners' metacognitive knowledge. The intervention program in their study comprised eight listening lessons, incorporating traditional listening exercises, individual reflections on their listening experience, and teacher-oriented discussions that focused on specific aspects of metacognitive knowledge about listening to teach metacognitive strategies to ten primary school learners. After the implementation of the intervention program, the participants reported a more thorough understanding of the nature and the demands of listening, increased confidence in dealing with listening tasks, and better strategic knowledge to cope with comprehension difficulties. The results also revealed that weaker learners benefited the most from this process-based approach to listening instruction.

In the same vein, Goh and Yusnita (2006) also conducted a study of metacognitive instruction for young listeners in which ten ESL learners went through an intervention program with eight listening lessons. The lesson plan focused on traditional listening exercises, learners' reflections on their listening experience, and post-listening discussions, which highlighted specific aspects of metacognitive knowledge about listening. The results indicated that all the learners reported a more tangible perception of the nature, demands, and the process of listening, more confidence to deal with listening tasks, and deeper strategic knowledge to tackle comprehension difficulties. 
Maximizing learners' metacognitive awareness in listening through metacognitive instruction

Mareschal (2007) also conducted a study through which he investigated the relationship between metacognitive awareness, listening comprehension performance, and self-regulatory abilities of ESL learners. The participants were two groups of native Canadians (low- and high-achievers), learning French as a Second Language. The results revealed that both low and high-proficiency learners benefited from the pedagogical approach presented to them through the study, and that this method raised the learners' metacognitive awareness and enhanced their listening comprehension performance.

In another study exploring the effect of metacognitive instruction on the listening performance of EFL learners; Coşkun (2010) conducted a study, which involved two groups of learners, a control and an experimental one, at a university in Turkey. The experimental group went through an intervention program in metacognition for five-weeks, which was embedded into their listening course book, while the control group did not. The results of the study showed that the participants in the experimental group outperformed their peers in the control group, and that their listening performance improved as a result of going through the intervention program.

Vandergrift and Tafaghodtari (2010) also conducted a study through which they strove to investigate the effect of metacognitive instruction on the listening performance and metacognitive awareness of 106 listeners, learning French as a Second Language. The participants in the experimental group went through an intervention program, informed by the process-based approach to teaching listening, which focused on prediction/planning, monitoring, evaluating, and problem solving within the pedagogical cycle, whereas the participants in the control group listened to the same materials, but without any attention to process. The results of the study revealed the significant impact of metacognitive instruction on the listening performance and metacognitive awareness of the participants in the experimental group in this study.

In an attempt to explore the relationship between metacognitive strategy use, motivation and listening performance, Baleghizadeh and Rahimi (2011) also conducted a study on 82 EFL learners in Iran. The results of their study revealed that the correlations between metacognitive strategy use and listening performance, listening performance, and intrinsic motivation, as well as metacognitive strategy use and intrinsic, extrinsic motivation were all statistically significant. In another attempt to examine the effect of metacognitive instruction on the listening performance, and metacognitive awareness of EFL learners, Bozorgian (2012) conducted a study on a group of high-intermediate learners in Iran. The participants went through a ten-week intervention program in metacognition, which focused on planning, monitoring, and evaluation. The results showed that metacognitive instruction helped high-intermediate learners develop their listening performance, but there was no immediate enhancement in their metacognitive awareness in listening as a result of metacognitive instruction.

In the same vein, Rahimi and Katal (2013) also tried to examine the effect of metacognitive instruction on metacognitive awareness, listening performance, and oral language proficiency of EFL learners in Iran, The participants in their study were fifty upper-intermediate learners, who went through a sixteen-week intervention program in metacognition. The results revealed that metacognitive instruction had a great impact on the learners' metacognitive awareness in the experimental group, but its impact on their listening performance fell short of statistical significance. Goh and $\mathrm{Hu}$ (2013) also tried to explore the relationship between the listening performance and metacognitive awareness of 113 Chinese ESL learners through IELTS and MALQ. To do so, the five different MALQ factors of metacognitive awareness related to listening comprehension were examined through the listeners' responses. The results of their study showed that there was a positive correlation between learners' metacognitive awareness and their listening performance, and that their metacognitive awareness accounted for $22 \%$ of the variance in listening comprehension.

In another recent study investigating the effect of metacognitive instruction on the listening performance, and metacognitive awareness of EFL learners, Bozorgian (2014) conducted a study on a group of 30 male High-intermediate listeners, who were learning English a Foreign Language in Iran. The participants in his study went through a pedagogical cycle in metacognition over a semester, which focused on planning, monitoring and 
Fahim, M. \& Fakhri Alamdari, E.

evaluation. The results showed that metacognitive instruction led to a great variance in the listening comprehension performance of EFL learners, but no enhancement in the metacognitive awareness of learners as a result of metacognitive instruction was reported.

In the most recent study exploring the effect of two different models of metacognitive instruction on the listening performance of EFL learners in Iran, Fahim and Fakhri (2015) conducted a study on 90 intermediate EFL listeners in three groups. The participants in experimental group one went through a ten-week intervention program that involved the instruction of ten metacognitive strategies, with its focus on planning, monitoring, and evaluation. The participants in experimental group two, who were trained through Metacognitive Pedagogical Sequence for ten weeks, went through an intervention program that engaged them in a sequence of tasks to help them develop metacognitive awareness of the processes underlying L2 listening through dialogic interactions. The participants in the control group, who went through a conventional listening instruction program, were taught by the same teacher and listened to the same materials without any guided attention to process. The results of their study showed that metacognitive instruction led to a considerable variance in the overall listening performance of learners. The results also revealed that the model of metacognitive instruction and the manner through which metacognitive strategies were orchestrated led to a difference in the listening performance of EFL learners in this study.

Needless to say, the focus of all the studies mentioned above is on the process of listening comprehension, which is often overlooked, or inadequately taken into account in the classroom in EFL contexts. However, in an attempt to make a meagre contribution to the field, the present study sought to explore the effect of metacognitive instruction on the listening performance, and metacognitive awareness of EFL learners through the following research questions:

1. Does metacognitive instruction have any effect on the listening performance of EFL learners?

2. Does metacognitive instruction have any effect on the metacognitive awareness of EFL learners?

\section{Method}

\subsection{Participants}

A group of 30 Iranian intermediate EFL learners, screened through an actual test of language proficiency, were chosen from all the available junior students majoring in English Translation within the Faculty of Foreign Languages at the Islamic Azad University, Qaemshahr Branch. The participants whose scores on the language proficiency test fell within \pm 1 standard deviation of the mean score were recognized as the eligible participants for this study. The sample comprised of 12 male and 18 female students with the age range of 20 to 24 . Out of the total 39 participants in this study, four of them declined to take part in either the pre- or post- administrations of the listening test. Two of them did not properly respond to the items in MALQ, and there were also three cases with a few missing answer for single items found in the listening test. All the participants had studied English for a minimum of nine years, but there was no metacognitive instruction in practice for them in their regular classes, either at school, or at the university.

\subsection{Instruments}

An actual test of language proficiency, validated and used by ETS at a worldwide test administration in 2003, was used as a standardized measure to check the homogeneity of subjects in terms of language proficiency and also it was used as a criterion to validate the listening comprehension test used as both pre and post-tests in this study. The second instrument used to measure the learners' listening comprehension performance in both preand post-tests was a listening comprehension test including 30 multiple choice items. The audio texts and the listening materials were adopted from Summit's Complete Assessment Package (Saslow \& Ascher, 2006). In 
Maximizing learners' metacognitive awareness in listening through metacognitive instruction

order to assess the reliability of the listening comprehension test, a pilot study was conducted with a sample group of 30 students, who had characteristics similar to those of the target group. The estimated internal consistency measures revealed that the adequate reliability of 0.80 was attained. In order to establish the empirical validity of the listening comprehension test, the Pearson product-moment correlation between the language proficiency and the listening test was calculated to be 0.74 , which was convincing enough for the purpose of this study.

The third instrument, used as both pre and post-questionnaire to assess learners' awareness and perceived use of listening strategies, was MALQ. The questionnaire, designed and validated by Vandergrift et al. (2006), consists of 21 items covering five factors: problem-solving, planning and evaluation, mental translation, person knowledge, and directed attention. Out of 21 items responded by the participants in this study, 18 were coded according to the Likert-scale points chosen by the learners, while the remaining three items ( 3 and 8 for person knowledge, and 16 for directed attention) were reverse coded (see Goh \& Hu 2013; Vandergrift et al. 2006) for further analyses.

\subsection{The Intervention Program}

Drawing on Vandergrift and Goh's (2012) metacognitive pedagogical sequence, the researchers designed a 10 -week intervention program through which the learners were encouraged to use dialogic interactions to negotiate metacognitive strategies they used while dealing with a listening task. Metacognitive instruction was not in practice for the learners in their normal classes throughout their education, and they were taught listening merely through a cycle of pre-listening, listening and post-listening activities. The intervention program used in this study consisted of five stages the researchers had to follow tightly to serve the purpose of conducting the ten-week program of metacognitive instruction.

Stage one dealt with planning and predicting. Every session, learners were given a new listening task based on which they had to brainstorm the kinds of information they might have heard, as well as any related vocabulary, and write their predictions in the listening guide sheet (see Fahim \& Fakhri, 2014). This prediction phase, which helped the listeners understand planning and associate it with their listening skill during their regular classroom activities, was done in pairs or in small groups.

Stage two, known as the first verification stage, engaged the learners in listening for the first time to measure their predictions about the topics and words used. At this stage, learners were guided to take note of some further information about the material they were listening to. This stage, with its focus on dialogic interactions, assisted the listeners to monitor their prediction of the listening text, their initial understanding, and their peer listening performance. It also assisted the listeners to pay more attention to details as they exchanged their notes and understanding through dialogues.

Stage three, known as the second verification stage, provided the opportunity for the listeners to listen to the same text anew so that they could figure out the points they had missed or misheard during the first time listening. They were also encouraged to work in pairs or groups to resolve the points of difficulty encountered after the first listening, make corrections if necessary, and note any new information down on their listening guide sheet. This stage, which paved the way for listeners to consider each other's listening performance, and develop an in-depth understanding of the listening through dialogues, helped them identify their listening problems through monitoring strategy.

Stage four focused on the final verification, which allowed the learners to listen to the same text for the third time in a row. This stage assisted listeners to identify any potential mishearing or misunderstanding and further helped them realize the new points they had not attended to during the first or second verification stage.

Stage five or the reflection stage, encouraged the listeners to evaluate their use of metacognitive strategies during the listening tasks. At this stage, the listeners were encouraged to complete personal reflections on the 
Fahim, M. \& Fakhri Alamdari, E.

listening process in their listening guide sheet, and note any strategies they would use in the subsequent sessions to deal with the listening task more readily.

The use of Metacognitive Pedagogical Sequence, along with the listening tasks and dialogic interactions, helped the listeners understand the use of metacognitive strategies. Having gone through the intervention program, the researchers invited the listeners to take a second listening test and MALQ, which took 60 minutes overall.

\section{Results}

To respond to the first research question focusing on the effect of metacognitive instruction on learners' listening comprehension, Wilcoxon signed-rank test, which is the non-parametric alternative to the paired sample t-test (Larson-Hall, 2010), was used to analyze the data. Table 1 shows the descriptive statistics of the overall results of the listeners' performance in both pre- and post-tests of listening.

\section{Table 1}

Descriptive statistics of overall listening scores for pre- and post-tests

\begin{tabular}{llllll}
\hline & & Mean & $n$ & $S D$ & SEM \\
\hline \multirow{2}{*}{ Pair 1 } & Pre-test & 19.93 & 30 & 3.52 & .643 \\
& & & & & \\
& Post-test & 27.83 & 30 & 1.80 & .328 \\
\hline
\end{tabular}

The means of overall scores in the single group pre- and post-tests of listening were 19.93 and 27.83 respectively (Table 1). Although the mean scores show a variance between the performances of listeners in preand post-tests, it is not clear if the differences are statistically significant. The results of Shapiro-Wilk showed that normality assumptions were violated $(p<.05)$. Thus, Wilcoxon signed-rank test was used to investigate whether there was a statistically significant difference between pre- and post-test performances of students in the listening test.

\section{Table 2}

Wilcoxon signed-rank test results comparing pre- and post-tests of listening

\begin{tabular}{lcccccc}
\hline & $n$ & $\begin{array}{c}\text { Mean } \\
\text { Ranks }\end{array}$ & $\begin{array}{c}\text { Sum of } \\
\text { Ranks }\end{array}$ & $Z$ & $\begin{array}{c}\text { Asymp. Sig. } \\
\text { (2-tailed) }\end{array}$ \\
\hline $\begin{array}{l}\text { Pair 1 } \\
\text { Post-test } \\
\text { Pre-test }\end{array}$ & $\begin{array}{c}\text { Negative } \\
\text { Ranks }\end{array}$ & 0 & .00 & .00 & & \\
& $\begin{array}{c}\text { Positive } \\
\text { Ranks }\end{array}$ & 30 & 15.50 & 465.00 & -4.794 & $>.000$ \\
& Ties & 0 & & & \\
& & & & & \\
\hline
\end{tabular}

The results of Wilcoxon signed-rank test (Table 2) showed that there was a statistically significant difference between pre- and post-test scores $(Z=-4.79 ; p=.000)$, suggesting that metacognitive instruction led to a positive variance on the overall post-test listening performance of the learners. With regard to the second research question focusing on the effect of metacognitive instruction on learners' metacognitive awareness, the overall results (Table 3 ) indicate that there is a difference in mean scores between the pre-test $(\mathrm{M}=85.16 ; \mathrm{SD}=$ 7.40) and the post-test ( $M=92.16$; $\mathrm{SD}=7.90)$ in the overall analysis of MALQ.

When the above means were compared statistically (Table 4), the differences between pre- and post-test results were found to be statistically significant $(\mathrm{t}=-6.30 ; p=.000)$, suggesting that metacognitive instruction did have an effect on the metacognitive awareness of learners. 
Maximizing learners' metacognitive awareness in listening through metacognitive instruction

Table 3

Descriptive statistics for the overall scores in pre- and post-tests of strategy questionnaire

\begin{tabular}{llllll}
\hline & & Mean & $n$ & $S D$ & SEM \\
\hline \multirow{2}{*}{ Pair 1 } & Pre-test & 85.16 & 30 & 7.40 & 1.35 \\
& & & & & \\
& Post-test & 96.53 & 30 & 7.76 & 1.41 \\
\hline
\end{tabular}

Table 4

Paired-Samples t-test results comparing pre-and post-tests of strategy questionnaire

\begin{tabular}{lcccccc}
\hline & Mean & $S D$ & $t$ & $d f$ & $p$ \\
\hline \multirow{2}{*}{ Pair 1 } & Pre-test - Post-test & -11.36 & 9,86 & -6.30 & 29 & .000 \\
\hline
\end{tabular}

\section{Discussion}

Research into metacognitive instruction in listening in both ESL and EFL contexts has gained recognition in recent years (Goh, 2008; Vandergrift, 2004; Vandergrift \& Goh, 2012). There are also a great number of empirical studies shedding light on the significance of metacognitive instruction in listening for language development ( see Baleghizadeh \& Rahimi, 2011; Bozorgian, 2012, 2014; Coskun, 2010; Fahim \& Fakhri, 2014; Goh \& Hu, 2013; Goh \& Taib, 2006; Goh \& Yusnita, 2006; Mareschal, 2007; Rahimi \& Katal, 2013; Vandergrift $\&$ Tafaghodtari, 2010). The results of these studies can undoubtedly substantiate the notion that metacognitive instruction in listening can be beneficial to language learners in a number of ways: First, it has a great impact not only on the process but also on the outcome of their learning (Goh, 2008; Wenden, 1998); second, metacognitive instruction makes learners process and store information more conveniently (Vandergrift, et al. 2006); third, it helps learners better cope with difficulties they encounter while dealing with a listening task (Goh, 2002); and above all, it can pave the way for them to self-regulate their learning (Wenden, 1998).

In an attempt to provide further empirical support for the body of research discussed above, this small-scale study was carried out to investigate the effect of metacognitive instruction on the learners' listening performance and their metacognitive awareness. Focusing on the first research question as to whether metacognitive instruction affects the learners' listening performance, the results revealed that metacognitive instruction has a positive effect on the listening performance of EFL learners. This finding seems to be consistent with those of the previous studies (see Baleghizadeh \& Rahimi, 2011; Bozorgian, 2012, 2014; Coskun, 2010; Fahim \& Fakhri, 2014; Goh \& Hu, 2013; Goh \& Taib, 2006; Goh \& Yusnita, 2006; Mareschal, 2007; Vandergrift \& Tafaghodtari, 2010), suggesting that metacognitive instruction through the process-based approach can facilitate L2 listening comprehension and lead to improvement in L2 listening. The results of this study with regard to the effect of metacognitive instruction on the listening performance of learners are, however, inconsistent with those of two other studies by Chen \& Haung (2011) and Rahimi \& Katal (2013), which found no immediate effect on enhancement of listening comprehension as a result of metacognitive instruction. These non-significant results could be attributed to such factors as the length of instruction, the role of context, and the learners' proficiency in listening comprehension, or as Chen \& Haung (2011) maintain, they could be due to listeners' characteristics as well as contextual factors.

The second research question strove to investigate the effect of metacognitive instruction on metacognitive awareness of EFL learners. The results revealed that metacognitive instruction through the process-based approach did raise the learners' metacognitive awareness of listening and led to improvement in all MALQ factors. This finding also seems to be in line with those of other studies (see Baleghizadeh \& Rahimi, 2011; Goh \& Hu, 2013; Goh \& Taib, 2006; Goh \& Yusnita, 2006; Mareschal, 2007; Rahimi \& Katal, 2013; Vandergrift \& Tafaghodtari, 2010), suggesting that the systematic instruction of metacognitive strategies through the process-based approach can raise learners' metacognitive awareness in listening. The finding of this study can 
also provide further empirical support for those of the previous studies mentioned above in which the participants went through metacognitive instruction within the pedagogical cycle, which fostered their listening comprehension ability, and raised their metacognitive awareness as a result. This finding is, nevertheless, incongruous with the results of two other studies by Bozorgian $(2012,2014)$ that found no immediate enhancement in high-intermediate learners' metacognitive awareness in listening as a result of metacognitive instruction. This non-significant result, as Bozorgian (2014) put it, could be attributed to such factors as: (I) the learners' inadequate familiarity with the metacognitive strategies, (II) their inadequate involvement to perceive the implications of these strategies, and (III) their failure to fully grasp the functions of these factors presented to them through MALQ.

This study is similar to the previous empirical studies in its pedagogy for teaching listening, and its focus on the process of teaching listening through metacognitive instruction. However, what makes this study distinct from the previous studies of its kind is the use of "Metacognitive Pedagogical Sequence", as a model of metacognitive instruction, which provided learners with ample opportunities to enrich individual learning through peer dialogs and cooperation throughout various phases of the listening tasks. Given the proficiency of learners as a determining factor for the success of any metacognitive intervention programs (Chamot \& Kupper, 1989), the learners in this study might not have been able to improve their listening performance and raise their metacognitive awareness had it not been for the model through which metacognitive instruction was presented to them. As a matter of fact, dialogic interactions, along with activities learners participated in within Metacognitive Pedagogical Sequence, contributed to the overall success of each individual, and led to a great variance in the listening performance and an increase in metacognitive awareness of learners in this study.

Listening comprehension is a skill that is usually taken for granted by many language learners, and most L2 learners do not generally regard it as a skill that requires the use of strategies. Thus, there is a lack of awareness among learners that these strategies can facilitate the listening process to a great extent (Cohen, 1998; Vandergrift, 1999). These findings, together with those of other studies, can add further empirical adequacy to the notion that listening comprehension and metacognitive awareness can both be fostered through metacognitive instruction within the classroom context. This process-based approach to listening can also encourage EFL learners to be actively involved in the process of listening, and can motivate them to find opportunities for self-regulated learning outside the classroom context.

In the same line, Vandergrift (2004) maintains that metacognitive instruction could be more beneficial to learners and help them more effectively with their listening performance if it is paired with the teaching of listening skill within a regular classroom context. Thus, for successful training of listeners, it is crucial to make them aware of the importance of strategy training in listening comprehension through incorporating strategies into their textbooks, and train them systematically about the concept of metacognition, and the role metacognition can play in learning. Once language learners are aware of successful strategies and know how to plan for a listening task, how to monitor their comprehension, and how to evaluate their performance, they become more effective learners, who can take on more responsibility for their own learning. In other words, once the learners are trained how to learn, they will become more effective learners and know how to cope with the complexities of the learning tasks better. This is in line with Vandergrift's (2002) comment that "teaching for metacognition provides language learners with the knowledge and tools for meaningful transfer of learning so that they know how to listen to and understand authentic texts outside of the classroom" (p. 573).

\section{Conclusions and pedagogical implications}

The present study was an attempt to explore the effect of metacognitive instruction on listening performance and metacognitive awareness of EFL learners in Iran. The results revealed that metacognitive instruction has a positive effect on the learners' listening performance, and can raise their metacognitive awareness. The findings can provide some directions for teachers on how to promote learners' metacognitive listening strategies through well-designed intervention programs. Teachers need to present the concept of language learning strategies to 
Maximizing learners' metacognitive awareness in listening through metacognitive instruction

learners and make them familiar with the learning strategies. This can help learners have better insight about listening tasks and listening strategies, and make them think about personal factors that may facilitate or impede the listening process. Teachers can also encourage learners to apply metacognitive strategies while dealing with different listening tasks and activities. This can increase their awareness about the listening process, which can lead to better performance in the long run. In doing so, learners become self-regulated listeners and can accomplish different tasks outside the classroom contexts. Thus, it is necessary for teachers to provide learners with ample opportunities to practice the new strategies in order to enable them to integrate these strategies into the process of language learning through peer dialogs and cooperation.

The findings of this study, along with those of the previous studies, are persuasive enough to oblige teachers to put an end to the conventional practices in listening instruction and focus on the process rather than the product of listening. In doing so, teachers will be able to make listening materials more accessible and more appealing to the listeners both in and out of the classroom context. Although this small-scale study provided further empirical support for the usefulness of metacognitive instruction in listening classes, the findings cannot be generalized to all EFL contexts due to such factors as the number of participants, the duration of the intervention program, the proficiency level of the learners, to name a few, which can all narrow the generalizability of the results. Therefore, there is an urgent need for further studies to explore the efficacy of metacognitive instruction with more participants through lengthier and more comprehensive intervention programs across different proficiency levels.

There is also a need for more research to investigate the effect of metacognitive instruction on different language skills in order to be able to claim that metacognitive instruction is effective in learning in general. This study also calls for more research in the area of systematic teaching of listening strategies with different strategy instruction models and test types to examine the effect of various instructional models on the listening performance and metacognitive awareness of learners. Last but not least, as few textbooks elaborate on listening tasks related to metacognitive strategies in Iran and many other EFL contexts, there is an urgent need to incorporate strategy-based tasks and activities into listening textbooks. To this end, teachers, teacher trainers, course book writers and curriculum designers need to be more aware of the benefits of strategy training and include these strategies in their lessons, course books and curricula.

\section{References:}

Anderson, N. J. (2002). The role of metacognition in second language teaching and learning. ERIC Digest. Retrieved Feb. 2013 from http://www.eric.ed.gov/PDFS/ED463659.pdf

Baleghizadeh, S., \& Rahimi, A. H. (2011). The relationship among listening performance, metacognitive strategy use and motivation from a self-determination theory perspective. Theory and Practice in Language Studies, 1, 61-67. http://dx.doi.org/10.4304/tpls.1.1.61-67

Berne, J. E. (2004). Listening comprehension strategies: A review of the literature. Foreign Language Annals, 4(37), 521-331. http://dx.doi.org/10.1111/j.1944-9720.2004.tb02419.x

Bozorgian, H. (2012). Metacognitive instruction does improve listening comprehension. ISRN Education, 1-6. http://dx.doi.org/10.5402/2012/734085

Bozorgian, H. (2014). The role of metacognition in the development of EFL learners' listening skill. International Journal of Listening, 28, 1-13.

Chamot, A., \& Küpper, L. (1989). Learning strategies in foreign language instruction. Foreign Language Annals, 22(1), 13-24. http://dx.doi.org/10.1111/j.1944-9720.1989.tb03138.x

Chen, C. C. \& Huang, C. T. (2011, October 28-28). Raising EFL college students' metacognitive awareness about listening. Paper presented at the NYS TESOL 41st Annual Conference, Melville, NY.

Cohen, A. D. (1998). Strategies in learning and using a second language. London: Longman.

Coşkun, A. (2010). The effect of metacognitive strategy training on the listening performance of beginner students. Research on Youth and Language, 4(1), 35-50.

DeKeyser, R. (2007). Practice in a second language: Perspectives from applied linguistics and cognitive 
psychology (Eds.). Cambridge: Cambridge University Press.

Dunkel, P. (1991). Listening in the native and second/foreign language: Toward an integration of research and practice. TESOL Quarterly, 25(3), 431-456. http://dx.doi.org/10.2307/3586979

Fahim, M., \& Fakhri, A. (2014). Exploring the effect of the model of metacognitive instruction on the listening performance of EFL learners. International Journal of Research Studies in Language Learning. http://dx.doi.org/10.5861/ijrs1l.2014.700

Flavell, J. H. (1976). Metacognitive aspects of problem solving. In L. B. Resnick (Ed.), The nature of intelligence (pp. 231-236). Hillsdale, NJ: Erlbaum.

Flavell, J. H. (1979). Metacognition and cognitive monitoring: A new area of cognitive-developmental inquiry. American Psychologist, 34, 906-911. http://dx.doi.org/10.1037/0003-066X.34.10.906

Goh, C. (2002). Learners' self-reports on comprehension and learning strategies for listening. Asian Journal of English Language Teaching, 12, 45-68.

Goh, C. (2008). Metacognitive instruction for second language listening development: Theory, practice and research implications. RELC Journal, 39(2), 188-213. http://dx.doi.org/10.1177/0033688208092184

Goh, C. (2010). Listening as process: Learning activities for self-appraisal and self-regulation. In N. Harwood, English language teaching materials (pp. 179-206). Cambridge: Cambridge University Press.

Goh, C., \& Hu, G. (2013). Exploring the relationship between metacognitive awareness and listening performance with questionnaire data. Language Awareness, 1-20. http://dx.doi.org/10.1080/09658416.2013.769558

Goh, C., \& Taib, Y. (2006). Metacognitive instruction in listening for young students. ELT Journal, 60, $222-232$. http://dx.doi.org/10.1093/elt/ccl002

Goh, C., \& Yusnita, T. (2006). Metacognitive instruction in listening for young learners. ELT Journal, 60(3), 222-232. http://dx.doi.org/10.1093/elt/ccl002

Graham, S. (2006). Listening comprehension: The students' perspective. System: An International Journal of Educational Technology and Applied Linguistics, 34(2), 165-182.

Hacker, D. J. (1998). Definitions and empirical foundations. In D. J. Hacker, J. Dunlosky, \& A. C. Graesser (Eds.), Metacognition in educational theory and practice (pp. 1-24). Mahwah, NJ: Lawrence Erlbaum Associates.

Larson-Hall, J. (2010). A guide to doing statistics in second language research using SPSS. London: Routledge.

Livingston, J. A. (1997). Metacognition: An overview. Retrieved April 2013 from http://www.gse.buffalo.edu/fas/shuell/cep564/Metacog.htm

Lynch, T. (2011). Academic listening in the 21st century: Reviewing a decade of research. Journal of English for Academic Purposes, 10(2), 79-88. http://dx.doi.org/10.1016/j.jeap.2011.03.001

Mareschal, C. (2007). Student perceptions of a self-regulatory approach to second language listening comprehension development. Unpublished doctoral dissertation, University of Ottawa, Ottawa, Ontario, Canada.

Mendelsohn, D. (1998). Teaching listening. Annual Review of Applied Linguistics, 18, 81-101. http://dx.doi.org/10.1017/S0267190500003494

Mendelsohn, D. (2001). Listening comprehension: We've come a long way, but. Contact, 27, 33-40.

Pressley, M. (2002). Metacognition and self-regulated comprehension. In A. E. Farstrup \& S. J. Samuels (Eds.), What research has to say about reading instruction (pp. 291-309). Newark, DE: International Reading Association.

Rahimi, M., \& Katal, M. (2013). The impact of metacognitive instruction on EFL learners' listening comprehension and oral language proficiency. Journal of Teaching Language Skills, 5(2), 69-90.

Rost, M. (2002). Teaching and researching listening. London: Pearson Education.

Saslow, J., \& Ascher, A. (2006). Summit 1: Complete assessment package. New York: Pearson Education, Inc.

Vandergrift, L. (1999). Facilitating second language listening comprehension: Acquiring successful strategies. ELT Journal, 5, 168-176. http://dx.doi.org/10.1093/elt/53.3.168

Vandergrift, L. (2002). It was nice to see that our predictions were right: Developing metacognition in L2 listening comprehension. The Canadian Modern Language Review, 58, 555-575. 
Maximizing learners' metacognitive awareness in listening through metacognitive instruction http://dx.doi.org/10.3138/cmlr.58.4.555

Vandergrift, L. (2004). Listening to learn or learning to listen? Annual Review of Applied Linguistics, 24, 3-25. http://dx.doi.org/10.1017/S0267190504000017

Vandergrift, L. (2007). Recent development in second and foreign language listening comprehension research. Language Teaching, 40, 191-210. http://dx.doi.org/10.1017/S0261444807004338

Vandergrift, L., \& Goh, C. (2012). Teaching and learning second language listening: Metacognition in action. New York: Rutledge.

Vandergrift, L., Goh, C., Mareschal, C., \& Tafaghodatari, M. H. (2006). The metacognitive awareness listening questionnaire (MALQ): Development and validation. Language Learning, 56, 431-462. http://dx.doi.org/10.1111/j.1467-9922.2006.00373.x

Vandergrift, L., \& Tafaghodtari, H. M. (2010). Teaching L2 students how to listen does make a difference: An empirical study. Language Learning, 60(2), 470-497. http://dx.doi.org/10.1111/j.1467-9922.2009.00559.x

Wenden, A. (1998). Metacognitive knowledge and language learning. Applied Linguistics, 19(4), 515-537. http://dx.doi.org/10.1093/applin/19.4.515 
Fahim, M. \& Fakhri Alamdari, E. 